\title{
Sources of Resistance to Pepino mosaic virus (PepMV) in Tomato
}

\author{
Salvador Soler-Aleixandre, C. López, J. Cebolla-Cornejo, and F. Nuez ${ }^{1}$ \\ Instituto de Conservación y Mejora de la Agrodiversidad Valenciana \\ (COMAV), Universidad Politécnica de Valencia, 46022 Valencia, Spain
}

Additional index words. potexvirus, Solanum lycopersicum, virus resistance

\begin{abstract}
The disease incited by Pepino mosaic virus (PepMV) is currently a serious problem for tomato (Solanum lycopersicum L.) crops in several European countries. A collection of accessions from different Solanum species was screened to find sources of resistance to PepMV. All plants of $S$. lycopersicum, $S$. lycopersicum var. cerasiforme, S. pennellii Correll, S. cheesmaniae (L. Riley) Fosberg, S. habrochaites S. Knapp \& D.M. Spooner, S. neorickii D.M. Spooner, G.J. Anderson \& R.K. Jansen, S. pimpinellifolium L., $S$. basendopogon Bitter, S. canense Rydb., S. caripense Humb. \& Bonpl. ex Dunal, and $S$. muricatum Aiton accessions showed a $\mathbf{1 0 0 \%}$ systemic infection rate, high viral accumulation, and apparent symptoms. In some accessions of the species $S$. chilense (Dunal) Reiche and $S$. peruvianum $L$., a variable percentage of plants without systemic infection was observed. Although all plants of ECU-335 accession of S. ochranthum Dunal showed systemic infection by PepMV, the symptoms were mild and the levels of viral accumulation were low. PepMV was not detected in plants of AN-CA-214 accession of $S$. pseudocapsicum L. No symptoms were observed either on inoculated leaves or on growing leaves. The use of the latter two species is limited considering that they cannot be sexually crossed with cultivated tomato. As a result, $S$. chilense and $S$. peruvianum are the most promising species in the search for sources of resistance to PepMV.
\end{abstract}

In 2004, more than 4 million ha of tomato (Solanum lycopersicum) were cultivated worldwide, producing over 116 million tonnes (FAO, 2005). This crop is the second horticultural species in terms of cultivated surface area and production volume after potato. In the last decades, the viral diseases have become the main limiting factor in tomato crops along the Spanish Mediterranean coast and in many other areas in the world. In this respect, Tomato spotted wilt virus (TSWV) and Tomato yellow leaf curl virus (TYLCV) have been responsible for serious economic losses around the world (Goldbach and Peters, 1994; Picó et al., 1996; Roselló et al., 1996).

Recently, other viral diseases have appeared such as those incited by Parietaria mottle virus (PMoV), which is currently causing serious damage in Greece (Lisa et al., 1998), France (Marchoux et al., 1999), Italy (Roggero et al., 2000), and Spain (Aramburu, 2001); Tomato infectious chlorosis virus (TICV), identified in the United States (Duffus et al., 1996), Italy (Vaira et al., 2002), and Spain (Font et al., 2003); and Tomato chlorosis virus (ToCV), identified in Portugal (Louro et al., 2000), Spain (NavasCastillo et al., 2000), and Greece (Dovas et al., 2002). Nevertheless, the viral disease that has caused the greatest impact on tomato crops is the one incited by Pepino mosaic virus (PepMV). This virus was first described in Solanum muricatum plants in Peru in 1974

Received for publication 14 June. 2006. Accepted for publication 28 July. 2006.

${ }^{1}$ To whom reprint requests should be addressed; e-mail fnuez@btc.upv.es.
(Jones et al., 1980). However, its presence was not reported again until 1999 when it was found in tomato crops in Holland. A few months later, its presence was reported in England and Germany in 100 ha infected (EPPO, 2000). In 2000, it was reported for the first time in the French region of Brittany and the Spanish provinces of Murcia, Almería, and the Canary Islands (Soler et al., 2000). It was later detected in Italy (Roggero et al., 2001), Canada, and the United States (French et al., 2001), Poland (Pospieszny and Borodynko, 2002), China (Zhang et al., 2003), and Hungary (Forray et al., 2004).

Currently, in Spain, the disease incited by PepMV affects plantations in the provinces of Alicante, Murcia, Almeria, Granada, and the Canary Islands and represents a serious problem for tomato crops along the Spanish Mediterranean coast. The highest incidence of the disease appears in Murcia with a $75 \%$ to $90 \%$ rate of infected greenhouses. In many cases, losses reach $20 \%$ to $40 \%$ of production (Soler et al., 2000). In addition, many countries are reticent to buy Spanish tomatoes because PepMV has been occasionally detected in Spanish imported fruits (Zitikaite et al., 2004)

Typical leaf symptoms associated with PepMV infection are yellow mosaics, puffiness, and leaf filimorphism. Dark green grooves appear on stems and sepals. Infected plants show a severe reduction of fruit set. Fruits usually show a mosaic of different shades of red only on ripe fruits, which is incited by an irregular distribution of lycopene on the surface and reduces their commercial value (Soler et al., 2000). The appearance of these symptoms depends on environmental factors, mainly temperature.
Symptom severity is reduced when temperature rises above $25^{\circ} \mathrm{C}$ and sometimes disappears altogether. In this case, plants may show spotted ripe fruits without symptoms on the leaves or may have systemic infection with high levels of viral accumulation without showing symptoms.

During the 1998-1999 season in Murcia, a sudden wilting of tomato plants was reported and in many cases caused the irreversible collapse of the plants. Studies carried out on collapsed and noncollapsed plants reported a clear association between PepMV and tomato collapse (Soler-Aleixandre et al., 2005b). This syndrome could constitute another symptom associated with infection by this potexvirus. This has contributed to the fact that PepMV is now considered to be one of the most serious limiting factors in the profitability of tomato crops in Spain. In Holland and the United Kingdom, the appearance of severe mosaic and filimorphism symptoms, associated with PepMV, also cause serious losses (Tomassoli, 2001). Fruit spotting causes the most damage in tomato crops in Italy (Roggero et al., 2001).

PepMV can be mechanically transmitted very efficiently. In the field, the disease spreads fast, even more than Potato virus $X$ (PVX), and can be transmitted more efficiently than Tomato mosaic virus (ToMV) (Wright and Mumford, 1999). It is transmitted through the touching of plants with contaminated hands, during the handling of infested tools, and even by clothes brushing against plants. Although it has been detected in tomato seeds (Salomone and Roggero, 2002), there is no evidence of transmission to descendants. No specific transmission vectors have been reported. The transmission role by contact of pollinating insects such as Bombus terrestris and B. canariensis, used in greenhouse crops, has been reported (Lacasa et al., 2003). Because of the lack of severe symptoms in infected plants, growers are reluctant to eliminate the infected ones and, therefore, the disease spreads quickly through greenhouses (Soler et al., 2000).

The highly efficient mechanical transmission of this disease has made the adoption of cultural practices unsuccessful in preventing its spread. The development of varieties that incorporate resistance to the virus would allow effective control of the disease. In this study, results of a screening for resistance to PepMV in a collection of accessions from different Solanum species are presented.

\section{Material and Methods}

Plant material. A total of 229 accessions from 15 different species of the Solanum genus were assayed for resistance to PepMV. The screening included accessions of Solanum basendopogon (one accession), S. canense (one), S. caripense (5), S. cheesmaniae (2), S. chilense (13), S. habrochaites (42), $S$. lycopersicum (54), S. lycopersicum var. cerasiforme (3), S. muricatum (9), S. neorickii (5), S. ochranthum (one), S. pennellii (9), $S$. peruvianum (45), S. pimpinellifolium (38), 
Table 1. Response of Solanum basendopogon, S. canense, S. caripense, S. cheesmaniae, S. chilense, S. habrochaites, S. lycopersicum, S. lycopersicum var. cerasiforme, S. muricatum, S. neorickii, $S$. ochranthum, $S$. pennellii, $S$. peruvianum, S. pimpinellifolium, and $S$. pseudocapsicum accessions to mechanical inoculation with the LE-2002 PepMV isolate.

\begin{tabular}{|c|c|c|c|c|}
\hline Accession & $\begin{array}{l}\text { Mean Maximum } \\
\text { Symptom Index }\end{array}$ & $\begin{array}{c}\text { Mean Maximum } \\
\text { Absorbance }^{\mathrm{y}}\end{array}$ & $\begin{array}{l}\text { Absorbance } \\
\text { Index }^{\mathrm{x}}\end{array}$ & $\begin{array}{c}\text { Total Percent } \\
\text { of Plants With } \\
\text { Systemic Infection }^{w} \\
\end{array}$ \\
\hline \multicolumn{5}{|l|}{ S. basendopogon } \\
\hline BIRM/S-1975 & 3.00 & 3.02 & 1.01 & 100.0 \\
\hline \multicolumn{5}{|l|}{ S. canense } \\
\hline BIRM/S-1815 & 3.17 & 3.06 & 1.02 & 100.0 \\
\hline \multicolumn{5}{|l|}{ S. caripense } \\
\hline PI-243342 & 3.33 & 2.45 & 0.82 & 100.0 \\
\hline 261 & 2.00 & 2.49 & 0.83 & 100.0 \\
\hline EC-36 & 2.67 & 2.62 & 0.88 & 100.0 \\
\hline BIRM/S-1034 & 2.67 & 2.75 & 0.92 & 100.0 \\
\hline E-7 & 3.42 & 3.06 & 1.02 & 100.0 \\
\hline \multicolumn{5}{|l|}{ S. cheesmaniae } \\
\hline GLP-36 & 3.8 & 2.96 & 0.99 & 100.0 \\
\hline GLP-3 & 2.4 & 2.99 & 1.00 & 100.0 \\
\hline \multicolumn{5}{|l|}{ S. chilense } \\
\hline PER-551 & 1,0 & 0.79 & 0.26 & 100.0 \\
\hline LA-470 & 1.1 & 1.03 & 0.30 & 30.0 \\
\hline ECU-527 & 0.88 & 0.97 & 0.33 & 80.0 \\
\hline PER-522 & 0.9 & 1.08 & 0.36 & 100.0 \\
\hline PER-526 & 0.75 & 1.15 & 0.39 & 100.0 \\
\hline PER-542 & 1.0 & 1.18 & 0.39 & 100.0 \\
\hline LA-1932 & 1.77 & 1.79 & 0.60 & 100.0 \\
\hline LA-1963 & 2.3 & 2.26 & 0.76 & 84.6 \\
\hline LA-1971 & 3.2 & 2.61 & 0.87 & 88.2 \\
\hline LA-1968 & 3.5 & 2.35 & 0.89 & 83.3 \\
\hline LA-2762 & 2.6 & 2.71 & 0.91 & 92.3 \\
\hline LA-2774 & 2.2 & 2.73 & 0.91 & 100.0 \\
\hline LA-458 & 3.6 & 2.75 & 0.92 & 78.6 \\
\hline \multicolumn{5}{|l|}{ S. habrochaites } \\
\hline ECU-436 & 1.6 & 3.00 & 1.00 & 100.0 \\
\hline ECU-910 & 2.77 & 3.02 & 1.01 & 100.0 \\
\hline ECU-922 & 2.0 & 0.44 & 0.15 & 100.0 \\
\hline ECU-926 & 1.93 & 0.56 & 0.19 & 100.0 \\
\hline ECU-968 & 1.2 & 0.60 & 0.20 & 100.0 \\
\hline ECU-911 & 2.27 & 0.59 & 0.20 & 100.0 \\
\hline ECU-921 & 2.20 & 0.61 & 0.21 & 100.0 \\
\hline ECU-908 & 2.33 & 0.65 & 0.22 & 100.0 \\
\hline ECU-764 & 0.78 & 0.68 & 0.23 & 100.0 \\
\hline ECU-800 & 1.25 & 0.78 & 0.26 & 100.0 \\
\hline ECU-753 & 1.35 & 0.77 & 0.26 & 100.0 \\
\hline ECU-869 & 1.23 & 0.89 & 0.30 & 100.0 \\
\hline ECU-847 & 0.9 & 0.93 & 0.31 & 100.0 \\
\hline ECU-872 & 2.13 & 1.01 & 0.33 & 100.0 \\
\hline ECU-851 & 1.57 & 1.01 & 0.34 & 100.0 \\
\hline ECU-870 & 1.40 & 1.11 & 0.37 & 100.0 \\
\hline ECU-924 & 1.47 & 1.09 & 0.37 & 100.0 \\
\hline ECU-888 & 1.80 & 1.10 & 0.37 & 100.0 \\
\hline ECU-862 & 2.27 & 1.13 & 0.38 & 100.0 \\
\hline ECU-854 & 2.13 & 1.31 & 0.44 & 100.0 \\
\hline ECU-758 & 2.27 & 1.33 & 0.45 & 100.0 \\
\hline ECU-849 & 0.5 & 1.38 & 0.46 & 100.0 \\
\hline ECU-846 & 1 & 1.40 & 0.47 & 100.0 \\
\hline ECU-865 & 1.00 & 1.42 & 0.48 & 100.0 \\
\hline ECU-856 & 1.17 & 1.52 & 0.51 & 100.0 \\
\hline ECU-950 & 2.5 & 1.56 & 0.52 & 100.0 \\
\hline ECU-760 & 1.57 & 1.63 & 0.55 & 100.0 \\
\hline ECU-852 & 1.4 & 1.78 & 0.60 & 100.0 \\
\hline ECU-850 & 2.27 & 1.83 & 0.61 & 100.0 \\
\hline ECU-859 & 1.40 & 1.81 & 0.61 & 100.0 \\
\hline ECU-776 & 2.7 & 1.89 & 0.63 & 100.0 \\
\hline ECU-868 & 1.87 & 1.87 & 0.63 & 100.0 \\
\hline ECU-863 & 1.50 & 2.08 & 0.70 & 100.0 \\
\hline ECU-855 & 1.47 & 2.14 & 0.72 & 100.0 \\
\hline ECU-860 & 1.73 & 2.16 & 0.72 & 100.0 \\
\hline ECU-871 & 1.97 & 2.48 & 0.81 & 100.0 \\
\hline ECU-864 & 1.73 & 2.45 & 0.82 & 100.0 \\
\hline ECU-909 & 1.80 & 2.50 & 0.84 & 100.0 \\
\hline ECU-816 & 2.8 & 2.68 & 0.90 & 100.0 \\
\hline ECU-923 & 2.20 & 2.75 & 0.92 & 100.0 \\
\hline ECU-524 & 2.8 & 2.81 & 0.94 & 100.0 \\
\hline ECU-434 & 2.8 & 2.85 & 0.95 & 100.0 \\
\hline \multicolumn{5}{|l|}{ S. lycopersicum ${ }^{\mathrm{v}}$} \\
\hline UPV-32 & 3,5 & 1.48 & 0.49 & 100.0 \\
\hline
\end{tabular}

continued and S. pseudocapsicum (one). Also, lines NE-1 and Fortuna-C of $S$. lycopersicum were included in all assays as susceptible controls. Seeds were treated at a temperature of $80{ }^{\circ} \mathrm{C}$ for $24 \mathrm{~h}$ to eliminate any possible contamination by ToMV. Afterward, they were soaked in 5\% sodium hypochlorite for 10 min to facilitate germination. The number of plants tested per accession varied between 10 and 20 by the lack of uniformity in the germination of the seeds. Once germinated, seedling were transplanted to $8 \times 6 \times 6 \mathrm{~cm}$ pots and grown at $25{ }^{\circ} \mathrm{C} / 18{ }^{\circ} \mathrm{C}$ (day/night) with a 14-h day length and relative humidity of $65 \% / 95 \%$ to $100 \%$ (day/night). Plants were subjected to irradiance of 65 to 85 $\mu \mathrm{mol} \cdot \mathrm{s}^{-1} \cdot \mathrm{m}^{-2}$ obtained through the use of Grolux tubes (Sylvania, Danvers, Mass.). Two plants per accession were kept as controls: one as an uninoculated control and another as a water-inoculated control. These controls were kept separately to avoid infection with PepMV.

Virus isolate and plant inoculation. PepMV isolate LE-2002 used in this study was obtained from tomato-infected plants collected in the region of Murcia (East of Spain). LE-2002 induces severe mosaics and leaf distortions and the full-length sequence of the genomic RNA was determined (López et al., 2005). The nucleotide sequence share identities higher than $99 \%$ with the strain reported in Europe (European tomato strain), which is the prevalent genotype in Spain (López et al., 2005; Pagán et al., 2006). To obtain the inoculum, leaves of tomato plants infected with LE-2002 isolate were crushed with a mortar and pestle until a uniform paste was obtained. The paste was mixed with sterile distilled water at a ratio of 1:5 (w/v) and filtered through a muslin cloth. Plants were mechanically inoculated at the fourth true leaf stage. The previously prepared inoculum was delivered to the four leaves using a cotton swab. The inoculation was repeated $7 \mathrm{~d}$ later, in new developed leaves, to guarantee infection and to prevent escapes.

Symptoms evaluation and plant analysis. Throughout the inoculation assays, the symptoms shown by each of the inoculated plants were recorded and compared with the noninoculated controls. A global index was used for the degree of symptoms observed (mosaic, filimorphism, and leaf curling): 0 , absence of symptoms; 1, mild symptoms; 2, moderate symptoms; 3 , severe symptoms; 4, very severe symptoms or dead plant.

Apical leaves, developed after the second inoculation, were taken at 30 and $60 \mathrm{~d}$ after inoculation (DAI). Leaves extracts of each plant were tested by double antibody sandwich enzyme-linked immunosorbent assay (DAS-ELISA) (Clark and Adams, 1977) using specific antiserum against PepMV (DSMZ GmbH, Braunschweig, Germany). Samples were mashed in extraction buffer at a dilution of $1: 20(\mathrm{w} / \mathrm{v})$ and $0.1 \mathrm{~mL}$ of the extract obtained was analyzed. The absorbance of the serologic reaction was measured using a Model 550 Microplate Reader (Bio Rad, Hercules, Calif.). Samples were considered to 
Table 1. (continued) Response of Solanum basendopogon, S. canense, S. caripense, S. cheesmaniae, $S$. chilense, $S$. habrochaites, $S$. lycopersicum, $S$. lycopersicum var. cerasiforme, S. muricatum, S. neorickii, S. ochranthum, S. pennellii, S. peruvianum, S. pimpinellifolium, and S. pseudocapsicum accessions to mechanical inoculation with the LE-2002 PepMV isolate.

\begin{tabular}{|c|c|c|c|c|}
\hline Accession & $\begin{array}{l}\text { Mean Maximum } \\
\text { Symptom Index }\end{array}$ & $\begin{array}{l}\text { Mean Maximum } \\
\text { Absorbance }^{\mathrm{y}}\end{array}$ & $\begin{array}{l}\text { Absorbance } \\
\text { Index }^{x}\end{array}$ & $\begin{array}{c}\text { Total Percent } \\
\text { of Plants With } \\
\text { Systemic Infection }^{\mathrm{w}}\end{array}$ \\
\hline CM-L-56 & 2.5 & 1.97 & 0.66 & 100.0 \\
\hline CB-1 & 2.1 & 2.54 & 0.85 & 100.0 \\
\hline CA-1 & 3.1 & 2.62 & 0.88 & 100.0 \\
\hline CL-1 & 2.6 & 2.70 & 0.9 & 100.0 \\
\hline NE-1 (susceptible control) & 2.5 & 2.71 & 0.91 & 100.0 \\
\hline CS-1 & 2.7 & 2.74 & 0.92 & 100.0 \\
\hline $\mathrm{CC}-1$ & 2.4 & 2.85 & 0.95 & 100.0 \\
\hline $\mathrm{CO}-1$ & 3.2 & 2.91 & 0.97 & 100.0 \\
\hline ECU-930 & 3.07 & 2.97 & 1.00 & 100.0 \\
\hline Fortuna-C (susceptible control) & 3.25 & 2.99 & 1.00 & 100.0 \\
\hline V-L-168 & 3.7 & 3.01 & 1.01 & 100.0 \\
\hline \multicolumn{5}{|l|}{ S. lycopersicum } \\
\hline \multicolumn{5}{|l|}{ var. cerasiforme } \\
\hline AN-L-133 & 2.9 & 2.90 & 0.97 & 100.0 \\
\hline GLP-22 & 3.7 & 3.00 & 1.00 & 100.0 \\
\hline GLP-26 & 3.4 & 3.00 & 1.00 & 100.0 \\
\hline \multicolumn{5}{|l|}{ S. muricatum } \\
\hline EC-46 & 1.79 & 2.33 & 0.78 & 100.0 \\
\hline Virú & 2.63 & 2.91 & 0.97 & 100.0 \\
\hline M-1 & 1.29 & 2.91 & 0.97 & 100.0 \\
\hline $152-A \times 6-7$ & 0.75 & 2.98 & 0.99 & 100.0 \\
\hline Lima & 0.83 & 3.00 & 1.00 & 100.0 \\
\hline EC-12 & 2.71 & 3.00 & 1.00 & 100.0 \\
\hline $11-48$ & 1.96 & 3.00 & 1.00 & 100.0 \\
\hline $37-A$ & 2.33 & 3.00 & 1.00 & 100.0 \\
\hline $7-2 \times 6-21$ & 2.75 & 3.03 & 1.01 & 100.0 \\
\hline \multicolumn{5}{|l|}{ S. neorickii } \\
\hline PE-51 & 2.7 & 2.55 & 0.85 & 100.0 \\
\hline PE-50 & 2.7 & 2.76 & 0.92 & 100.0 \\
\hline PE-52 & 4 & 2.89 & 0.97 & 100.0 \\
\hline ECU-446 & 3.8 & 2.90 & 0.97 & 100.0 \\
\hline ECU-448 & 4 & 2.92 & 0.98 & 100.0 \\
\hline \multicolumn{5}{|l|}{ S. ochrantum } \\
\hline ECU-335 & 0.6 & 0.14 & 0.04 & 100.0 \\
\hline \multicolumn{5}{|l|}{ S. pennellii } \\
\hline ECU-831 & 2.18 & 1.30 & 0.43 & 100.0 \\
\hline ECU-840 & 2.35 & 1.35 & 0.45 & 100.0 \\
\hline ECU-832 & 3.47 & 2.55 & 0.85 & 100.0 \\
\hline ECU-836 & 3.53 & 2.55 & 0.85 & 100.0 \\
\hline ECU-837 & 3.63 & 2.74 & 0.92 & 100.0 \\
\hline LA-716 & 2.4 & 2.76 & 0.92 & 100.0 \\
\hline ECU-835 & 3.50 & 2.81 & 0.94 & 100.0 \\
\hline PE-45 & 3.6 & 2.91 & 0.97 & 100.0 \\
\hline PE-47 & 3.5 & 3.02 & 1.01 & 100.0 \\
\hline \multicolumn{5}{|l|}{ S. peruvianum } \\
\hline ECU-947 & 0.5 & 0.53 & 0.18 & 100.0 \\
\hline CIAPAN-16 & 0.5 & 0.70 & 0.23 & 77.8 \\
\hline PI-212407 & 3.0 & 0.74 & 0.38 & 90.0 \\
\hline ECU-778 & 1.25 & 0.80 & 0.41 & 100.0 \\
\hline PI-126441 & 2.37 & 0.90 & 0.46 & 100.0 \\
\hline PI-251311 & 3.5 & 0.94 & 0.48 & 95.0 \\
\hline ECU-946 & 2.7 & 0.97 & 0.32 & 100.0 \\
\hline LA-1537 & 2.05 & 1.09 & 0.55 & 100.0 \\
\hline ECU-953 & 2.97 & 1.11 & 0.37 & 100.0 \\
\hline ECU-944 & 2.73 & 1.13 & 0.38 & 100.0 \\
\hline ECU-969 & 3.5 & 1.22 & 0.62 & 100.0 \\
\hline ECU-771 & 2.67 & 1.73 & 0.58 & 100.0 \\
\hline ECU-765 & 2.97 & 1.78 & 0.59 & 100.0 \\
\hline ECU-964 & 2.60 & 1.91 & 0.64 & 100.0 \\
\hline CIAPAN-15 & 0.7 & 1.92 & 0.64 & 83.3 \\
\hline ECU-804 & 1.97 & 1.99 & 0.67 & 100.0 \\
\hline ECU-766 & 2.5 & 2.21 & 0.74 & 100.0 \\
\hline ECU-798 & 2.63 & 2.23 & 0.75 & 100.0 \\
\hline ECU-775 & 2.6 & 2.28 & 0.76 & 100.0 \\
\hline ECU-777 & 2.5 & 2.32 & 0.78 & 100.0 \\
\hline ECU-779 & 2.77 & 2.33 & 0.78 & 100.0 \\
\hline ECU-783 & 2.63 & 2.36 & 0.79 & 100.0 \\
\hline ECU-788 & 2.83 & 2.51 & 0.84 & 100.0 \\
\hline ECU-784 & 2.53 & 2.52 & 0.84 & 100.0 \\
\hline ECU-807 & 2.47 & 2.56 & 0.86 & 100.0 \\
\hline ECU-952 & 2.97 & 2.60 & 0.87 & 100.0 \\
\hline ECU-813 & 3.23 & 2.61 & 0.87 & 100.0 \\
\hline
\end{tabular}

continued be infected (DAS-ELISA-positive) when absorbance was greater than three times the average absorbance of the samples from healthy control plants $(\approx 0.06$ absorbance units). Samples were considered to be noninfected (DAS-ELISA-negative) when the absorbance value was below this threshold. The absorbance values of the immunoenzymatic reaction were used as an indirect estimate of the viral accumulation (Ding et al., 1995, Lankes, 2003). To be able to compare the viral accumulation levels between accessions, an absorbance index (I) was calculated as the ratio of maximum mean absorbance of an accession to maximum mean absorbance of the susceptible Fortuna-C control.

Plants without systemic infection at 60 DAI (DAS-ELISA-negative in apical uninoculated leaves) were minutely analyzed at 75 DAI to confirm the absence of PepMV. For this purpose, samples of the stem were taken every $10 \mathrm{~cm}$ starting at the stem base and were analyzed along with samples from apical leaves and roots. Plants tested DAS-ELISAnegative in each of the samples were also analyzed by reverse transcriptase-polymerase chain reaction (RT-PCR) to control again for the absence of PepMV (López et al., 2005).

\section{Results}

Screening assay. Yellow mosaic was observed at 7 DAI in the inoculated leaves of the controls NE-1 and Fortuna-C. Leaf mosaic did not appear on the uninoculated leaves, but at 30 to $45 \mathrm{DAI}$, development of filimorphism, or curling of the leaflets, was observed (data not shown). Throughout the assay, the symptoms became more acute, particularly the filimorphism, and all susceptible control plants became systemically infected in all assays (Table 1).

All plants from the accessions of Solanum basendopogon, $S$. canense, $S$. caripense, $S$. cheesmaniae, S. lycopersicum, S. lycopersicum var. cerasiforme, $S$. muricatum, $S$. neorickii, and $S$. pennellii showed systemic infection (Table 1). The absorbance was very high in most of the accessions and the symptoms consisted of moderate to very severe mosaics and filimorphism in leaves. In some of the accessions, the incidence of the disease was so strong that up to $33.3 \%$ of the plants died. Only one $(1.85 \%) S$. lycopersicum accession (UPV-32) and two (22.2\%) S. pennellii accessions (ECU-831 and ECU-840) showed an absorbance index lower than 0.5.

All plants from the accessions of $S$. habrochaites and $S$. pimpinellifolium also showed systemic infection (Table 1). Nevertheless, in these species, variable degrees of viral accumulation were observed. A total of $22(52 \%)$ S. habrochaites accessions and $12(31 \%)$ $S$. pimpinellifolium accessions gave absorbance values lower than $50 \%$ (I $<0.5)$ of the corresponding susceptible Fortuna-C control. This reduction in the absorbance did not mean that there was an absence of symptoms. Only some $S$. habrochaites accessions (ECU-764, ECU847, and ECU-849) showed mild symptoms. The rest of accessions showed moderate or severe symptoms. 
Table 1. (continued) Response of Solanum basendopogon, S. canense, S. caripense, S. cheesmaniae, S. chilense, $S$. habrochaites, $S$. lycopersicum, $S$. lycopersicum var. cerasiforme, S. muricatum, S. neorickii, S. ochranthum, S. pennellii, S. peruvianum, S. pimpinellifolium, and S. pseudocapsicum accessions to mechanical inoculation with the LE-2002 PepMV isolate.

\begin{tabular}{|c|c|c|c|c|}
\hline Accession & $\begin{array}{l}\text { Mean Maximum } \\
\text { Symptom Index }\end{array}$ & $\begin{array}{c}\text { Mean Maximum } \\
\text { Absorbance }^{\mathrm{y}}\end{array}$ & $\begin{array}{l}\text { Absorbance } \\
\text { Index }^{x}\end{array}$ & $\begin{array}{c}\text { Total Percent } \\
\text { of Plants With } \\
\text { Systemic Infection }^{\text {w }}\end{array}$ \\
\hline ECU-802 & 2.97 & 2.62 & 0.88 & 100.0 \\
\hline ECU-801 & 3.03 & 2.63 & 0.88 & 100.0 \\
\hline PE-20 & 2.28 & 2.65 & 0.89 & 100.0 \\
\hline ECU-785 & 3.17 & 2.66 & 0.89 & 100.0 \\
\hline ECU-809 & 3.20 & 2.67 & 0.89 & 100.0 \\
\hline ECU-793 & 2.77 & 2.67 & 0.89 & 100.0 \\
\hline ECU-803 & 2.67 & 2.68 & 0.90 & 100.0 \\
\hline CIAPAN-17 & 1.4 & 2.69 & 0.9 & 100.0 \\
\hline ECU-791 & 2.77 & 2.71 & 0.91 & 100.0 \\
\hline PE-18 & 1.5 & 2.77 & 0.93 & 100.0 \\
\hline ECU-790 & 2.90 & 2.78 & 0.93 & 100.0 \\
\hline PI-126944 & 2.4 & 2.79 & 0.93 & 100.0 \\
\hline PE-19 & 2.53 & 2.84 & 0.95 & 100.0 \\
\hline PI-143679 & 1.0 & 2.87 & 0.96 & 100.0 \\
\hline LA-1708 & 2.7 & 2.88 & 0.96 & 100.0 \\
\hline ECU-811 & 3.53 & 2.88 & 0.96 & 100.0 \\
\hline PI-126935 & 1.4 & 2.93 & 0.98 & 100.0 \\
\hline ECU-821 & 3.63 & 2.97 & 0.99 & 100.0 \\
\hline \multicolumn{5}{|c|}{ S. pimpinellifolium } \\
\hline LA-1587 & 3.0 & 0.35 & 0.12 & 100.0 \\
\hline ECU-879 & 2.17 & 0.54 & 0.18 & 100.0 \\
\hline ECU-951 & 3.57 & 0.57 & 0.19 & 100.0 \\
\hline ECU-877 & 2.40 & 0.65 & 0.22 & 100.0 \\
\hline ECU-878 & 2.60 & 0.76 & 0.25 & 100.0 \\
\hline ECU-853 & 1.92 & 0.76 & 0.25 & 100.0 \\
\hline ECU-893 & 3.5 & 0.94 & 0.31 & 100.0 \\
\hline ECU-873 & 1.9 & 0.97 & 0.32 & 100.0 \\
\hline ECU-701 & 1.57 & 1.08 & 1.09 & 100.0 \\
\hline ECU-966 & 2.47 & 1.08 & 0.36 & 100.0 \\
\hline ECU-874 & 2.83 & 1.12 & 0.38 & 100.0 \\
\hline ECU-875 & 2.47 & 1.18 & 0.39 & 100.0 \\
\hline ECU-749 & 2.97 & 1.18 & 0.40 & 100.0 \\
\hline ECU-742 & 3.07 & 1.54 & 0.52 & 100.0 \\
\hline ECU-745 & 2.83 & 1.56 & 0.52 & 100.0 \\
\hline ECU-693 & 1.53 & 1.62 & 0.54 & 100.0 \\
\hline ECU-727 & 3.13 & 1.69 & 0.57 & 100.0 \\
\hline ECU-711 & 3.37 & 1.69 & 0.57 & 100.0 \\
\hline ECU-739 & 2.57 & 1.76 & 0.59 & 100.0 \\
\hline ECU-748 & 3.17 & 2.18 & 0.73 & 100.0 \\
\hline ECU-738 & 2.70 & 2.28 & 0.76 & 100.0 \\
\hline ECU-867 & 3.2 & 2.29 & 0.77 & 100.0 \\
\hline ECU-744 & 2.60 & 2.32 & 0.78 & 100.0 \\
\hline ECU-750 & 2.77 & 2.48 & 0.83 & 100.0 \\
\hline ECU-707 & 3.30 & 2.52 & 0.84 & 100.0 \\
\hline ECU-712 & 3.23 & 2.57 & 0.86 & 100.0 \\
\hline ECU-713 & 3.63 & 2.60 & 0.87 & 100.0 \\
\hline ECU-692 & 3.17 & 2.64 & 0.88 & 100.0 \\
\hline ECU-710 & 3.27 & 2.68 & 0.90 & 100.0 \\
\hline ECU-736 & 3.07 & 2.70 & 0.90 & 100.0 \\
\hline ECU-709 & 2.87 & 2.74 & 0.92 & 100.0 \\
\hline ECU-702 & 3.27 & 2.80 & 0.94 & 100.0 \\
\hline ECU-604 & 2.4 & 2.93 & 0.98 & 100.0 \\
\hline ECU-603 & 3.2 & 2.95 & 0.99 & 100.0 \\
\hline ECU-579 & 3.6 & 2.97 & 0.99 & 100.0 \\
\hline ECU-927 & 3.23 & 2.97 & 1.00 & 100.0 \\
\hline ECU-928 & 3.10 & 2.99 & 1.00 & 100.0 \\
\hline ECU-660 & 2.8 & 3.01 & 1.00 & 100.0 \\
\hline \multicolumn{5}{|c|}{ S. pseudocapsicum } \\
\hline AN-CA-214 & 0.0 & - & - & 0.0 \\
\hline
\end{tabular}

${ }^{\mathrm{z}}$ Mean value of the maximum symptom index of the plants of each accession ( 0 , absence of symptoms 1, mild symptoms; 2 , moderate symptoms; 3 , severe symptoms; 4 , very severe symptoms or dead plant).

${ }^{\mathrm{y}}$ Mean value of the maximum DAS-ELISA absorbance of the plants with systemic infection for each accession.

${ }^{x}$ Ratio of mean maximum DAS-ELISA absorbance of each accession to mean maximum absorbance of Fortuna-C.

${ }^{\text {w}}$ Percentage of plants that showed systemic infection at least once during the duration of the assay.

${ }^{v}$ Of the 54 accessions tested from S. lycopersicum, only 12 are included because the results of the remaining 42 accessions were consistent with those observed for the 12 reported accessions.

In bold font, accessions showing some DAS-ELISA-negative plant.
Only in some $S$. chilense and S. peruvianum accessions were detected plants without systemic infection (Table 1). Seven (53.8\%) S. chilense accessions (ECU-527, LA-458, LA-470, LA-1963, LA-1968, LA-1971, and LA-2762) showed variable percentages of presumably resistant plants without systemic infection or symptoms. The same was true in four $(8.9 \%)$ S. peruvianum accessions (CIAPAN-15, CIAPAN-16, PI-212407, and PI251311). The only accession of $S$. ochranthum (ECU-335) showed systemic infection in all plants at $30 \mathrm{DAI}$, although the symptoms were mild (symptom index $=0.6$ ). In addition, only $13.3 \%$ of the plants were systemically infected at 60 DAI and the levels of absorbance were low with mean absorbance values of 0.134 at 30 DAI and 0.030 at 60 DAI (data not shown). Finally, PepMV was not detected in any of the plants of accession AN-CA-214 of S. pseudocapsicum (Table 1). No symptoms at all were observed in the inoculated leaves or in the other leaves developed after inoculation.

Analysis of plants without systemic infection. Plants without systemic infection at 60 DAI were minutely analyzed at 75 DAI to confirm the absence of PepMV. The samples of stem, apical leaves and roots of all Fortuna-C plants showed infection by PepMV (Table 2). All $S$. chilense and $S$. peruvianum plants without systemic infection in the previous assay, except three plants of LA-470, showed infection by PepMV at least in one of the analyzed samples (apical leaves, stem, and root) at 75 DAI (Table 2). S. chilense and $S$. peruvianum-infected plants showed a basipetal distribution of the virus with the maximum level of viral accumulation in the basal part of the plant stems. None of the samples of $S$. ochranthum and $S$. pseudocapsicum tested were DAS-ELISA-positive (Table 2). DASELISA-negative plants of accessions LA-470, ECU-335, and AN-CA-214 were RT-PCR analyzed to confirm absence of PepMV. The presence of the virus was detected in all plants of LA-470 and ECU-335 identified as DASELISA-negative, but not in AN-CA-214 plants of $S$. pseudocapsicum (Fig. 1).

\section{Discussion}

The results obtained suggest that $S$. chilense is the most promising Solanum species in the search for sources of resistance to PepMV. This species has been also used for introgressing resistance to the fungus Leivellula taurica (Stamova and Yordanov, 1987) and to other viruses such as Tomato yellow leaf curl virus (TYLCV) (Zamir et al., 1994), Cucumber mosaic virus (CMV) (Stamova and Chetelat, 2000), and Tomato spotted wilt virus (TSWV) (Canady et al., 2001) in the cultivated tomato. Otherwise, some accessions of $S$. habrochaites, $S$. peruvianum, and $S$. pimpinellifolium showed significant reduction in absorbance after being inoculated with PepMV as described previously (Soler-Aleixandre et al., 2005a). It would be necessary to carry out 
field assays to determine if this reduction is sufficient to attenuate the damage of spotted fruits and abortion of flowers incited by PepMV.

Higher levels of resistance were detected in accession ECU-335 of S. ochranthum. Although $100 \%$ of ECU-335 plants showed systemic infection by PepMV at first, the absorbance was low. This accumulation decreased gradually with time. The drastic disappearance of symptoms could be the result of this reduction of accumulation of the virus in the plant organs. In this sense, all inoculated plants became infected initially and afterward, all of them showed no infection in the apical leaves. The positive absorbance values detected in some plants at $30 \mathrm{DAI}$ could be because the samples were taken from inoculated leaves, in which PepMV had been deposited during inoculation. This is highly improbable because $30 \mathrm{~d}$ had elapsed between the last inoculation and the first sample-taking. During this time, four new leaves developed, which were precisely the ones that were sampled. DAS-ELISA analysis indicates that virus had disappeared in the inoculated plants of ECU-335. RT-PCR analysis of these plants suggests that the virus is randomly distributed in some parts of the plant at low concentrations.

The accession AN-CA-214 of S. pseudocapsicum showed total resistance to mechanical inoculation with PepMV. No symptoms associated with PepMV infection were observed. Likewise, none of the inoculated leaves showed signs of developing local lesions that could suggest a hypersensitive response. This allows the ruling out of this mechanism as being responsible for resistance. RT-PCR results confirm that plants of this accession remain virus-free.

The stem analysis of $S$. chilense and $S$. peruvianum plants, selected as resistant at 60 DAI, clearly demonstrates the existence of an asymmetric distribution of the virus in the stem. This type of distribution had already been detected in tomato plants infected by PepMV in the region of Murcia (SolerAleixandre et al., 2005b). The lowest absorbance values were obtained in the youngest parts of the plants. In some plants, the presence of the virus in the apical leaves was not detected. This distribution could explain that some plants of $S$. chilense and S. peruvianum were DAS-ELISA-negative in apical leaves at 60 DAI and DAS-ELISApositive in the stem at 75 DAI. These results mean that in future searches for sources of resistance, the absence of the virus in plants classified as resistant must be checked.

Having materials with a high level of resistance to PepMV at one's disposal is a great achievement. Nevertheless, $S$. pseudocapsicum cannot be crossed with cultivated tomato plants. In this case, somatic hybridization or other techniques could allow the transfer of the identified resistance to commercial tomato varieties. The identification of reduced viral accumulation in some plants of the accession LA-470 of $S$. chilense could

Table 2. Serologic analysis by DAS-ELISA of plants classified as resistant in the screening assay.

\begin{tabular}{|c|c|c|c|c|c|c|}
\hline \multirow[b]{2}{*}{ Accession } & \multirow{2}{*}{$\begin{array}{l}\text { No. of Selected/Infected } \\
\text { Plants }^{\mathrm{z}}\end{array}$} & \multicolumn{5}{|c|}{ Mean Absorbance } \\
\hline & & $\overline{\mathrm{A}^{\mathrm{y}}}$ & $\mathrm{S} 30^{\mathrm{x}}$ & $\mathrm{S} 20^{\mathrm{w}}$ & $\mathrm{S} 10^{\mathrm{v}}$ & $\overline{\mathrm{R}^{\mathrm{u}}}$ \\
\hline \multicolumn{7}{|l|}{$\overline{S . \text { chilense }}$} \\
\hline ECU-527 & $4 / 4$ & 0,21 & 0,51 & 0,85 & 1,45 & 1,50 \\
\hline LA-458 & $2 / 2$ & 0,45 & 1,60 & 2,31 & 2,88 & 2,91 \\
\hline LA-470 & $7 / 4$ & 0,01 & 0,02 & $\mathbf{0 , 5 0}$ & 0,08 & 0,11 \\
\hline LA-1963 & $2 / 2$ & 0,65 & 1,14 & 1,74 & 1,80 & 2,31 \\
\hline LA-1968 & $3 / 3$ & 0,91 & 1,37 & 2,01 & 2,21 & 2,38 \\
\hline LA-1971 & $2 / 2$ & 0,23 & 1,35 & 1,84 & 2,45 & 2,18 \\
\hline LA-2762 & $1 / 1$ & 0,36 & 1,46 & 2,11 & 2,75 & 2,62 \\
\hline \multicolumn{7}{|l|}{ S. peruvianum } \\
\hline CIAPAN-15 & $3 / 3$ & 0,42 & 0,98 & 1,11 & 1,54 & 1,84 \\
\hline CIAPAN-16 & $4 / 4$ & 0.12 & 0,78 & 0,95 & 0,98 & 1,45 \\
\hline PI-212407 & $3 / 3$ & 0,30 & 0,12 & 0,85 & 1,31 & 1,70 \\
\hline PI-251311 & $2 / 2$ & 0,11 & 0,24 & 0,27 & 0,78 & 1,11 \\
\hline \multicolumn{7}{|l|}{ S. ochranthum } \\
\hline ECU-335 & $13 / 0$ & 0,01 & $\mathbf{0 , 0 0}$ & 0,01 & 0,01 & $\mathbf{0 , 0 1}$ \\
\hline \multicolumn{7}{|l|}{ S. pseudocapsicum } \\
\hline AN-CA-214 & $15 / 0$ & 0,01 & 0,01 & $\mathbf{0 , 0 2}$ & 0,01 & $\mathbf{0 , 0 1}$ \\
\hline \multicolumn{7}{|l|}{ S. lycopersicum } \\
\hline Fortuna-C (susceptible control) & $12 / 12$ & 1,68 & 2,17 & 2,84 & 3,06 & 2,92 \\
\hline
\end{tabular}

${ }^{\mathrm{z}}$ Number of plants selected as resistant in screening assay/number of plants infected in at least one of the analyzed zones.

${ }^{\text {y} A p i c a l ~ l e a f ~ s a m p l e . ~}$

${ }^{\mathrm{x}}$ Stem sample $30 \mathrm{~cm}$ from stem base.

${ }^{w}$ Stem sample $20 \mathrm{~cm}$ from stem base.

'Stem sample $10 \mathrm{~cm}$ from stem base.

"Root sample.

In bold font, accessions showing some DAS-ELISA-negative plant.

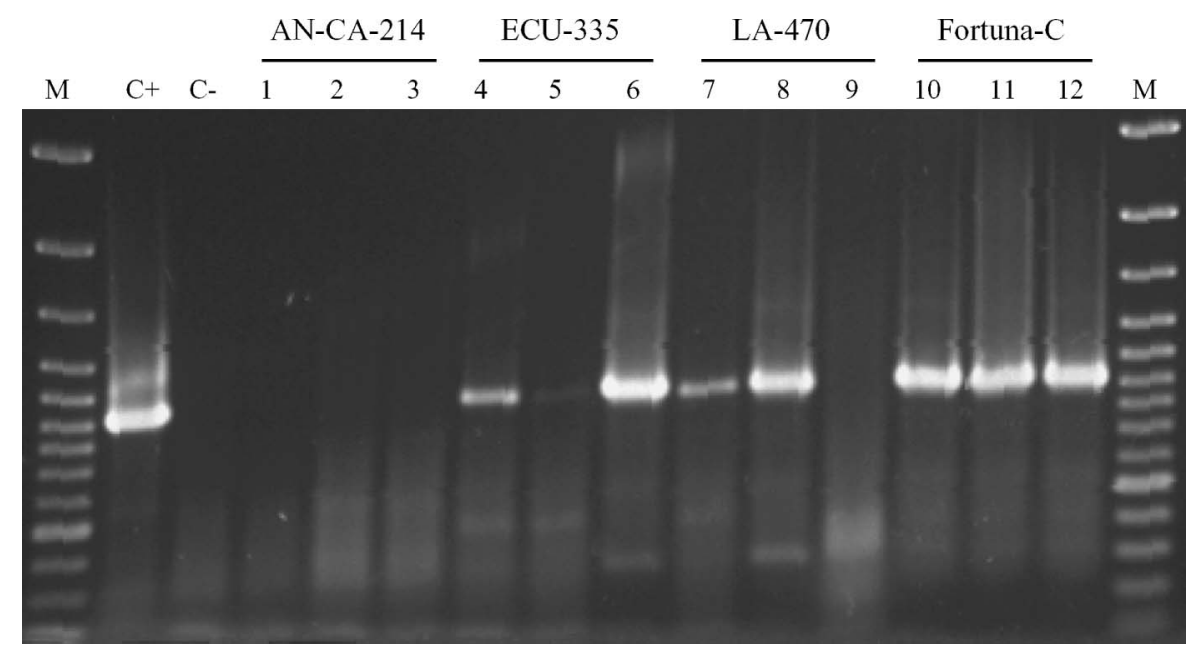

Fig. 1. Reverse transcriptase-polymerase chain reaction detection of PepMV in plants classified as resistant from accessions LA-470 (S. chilense), ECU-335 (S. ochranthum), and AN-CA-214 (S. pseudocapsicum) and Fortuna-C (S. lycopersicum) as susceptible control. The templates used were apical leaves (lanes 1, 4, 7, and 10), stem (lanes 2, 5, 8, and 11) and stem base (lanes 3, 6, 9, and 12). $\mathrm{C}^{+}$and $\mathrm{C}^{-}$: positive and negative NE-1 controls from infected and noninoculated plants, respectively. $\mathrm{M}$, molecular size marker.

allow the development of varieties resistant to PepMV because hybrids with tomato can be obtained. However, search for new sources of resistance in this species must be thoroughly advanced, because this could be useful for the short term in the development of varieties of tomato resistant to PepMV.

\section{Literature Cited}

Aramburu, J. 2001. First report of Parietaria mottle ilarvirus on tomato in Spain. Plant Dis. 85:1210.

Canady, M.A., M.R. Stevens, M.S. Barineau, and J.W. Scott. 2001. Tomato Spotted Wilt Virus (TSWV) resistance in tomato derived from
Lycopersicon chilense Dun. LA 1938. Euphytica 117:19-25.

Clark, M.F. and A.N. Adams. 1977. Characteristics of the microplate method of enzyme-linked immunosorbent assay (ELISA) for the detection of plant viruses. J. Gen. Virol. 34:475-483.

Ding, X.S., M.H. Shintaku, S.A. Arnold, and R.S. Nelson. 1995. Accumulation of mild and severe strains of Tobacco mosaic virus in minor veins of tobacco. Mol. Plant Microbe Interact. 8: 32-40.

Dovas, C.I., N.I. Katis, and A.D. Avgelis. 2002. Multiplex detection of crinivirus associated with epidemics of a yellowing disease of tomato in Greece. Plant Dis. 86:1345-1349.

Duffus, J.E., H.Y. Liu, and G.C. Wisler. 1996 Tomato infectious chlorosis virus-a new 
clostero-like virus transmitted by Trialeurodes vaporariorum. Eur. J. Plant Pathol. 102: 219-226.

EPPO. 2000. EU survey on Pepino mosaic potexvirus. 15 July 2003. http://www.maff.gov.uk/ planth/pestnote/pepino.htm

FAO. 2005. FAOSTAT. Base de datos de estadísticos. 10 Nov. 2005. http://www.fao.org.

Font, M.I., A.M. Vaira, G.P. Accotto, A. Lacasa, J. Serra, J. Gomila, M. Juarez, A.I. Espino, and M.C. Jordá. 2003. Yellowing of tomato crops associated with Tomato chlorosis virus (ToCV) and Tomato infectious chlorosis virus (TICV) in Spain. Bol. Sanid. Veg., Plagas 29:109-121.

Forray, A., M. Tuske, and R. Gaborianyi. 2004 First report of the occurrence of Pepino mosaic virus in Hungary. Novenyvedelem (Bp.1965) 40:471-473

French, C.J., M. Bouthillier, M. Bernardy, G. Ferguson, M. Sabourin, R.C. Johnson, C. Masters, S. Godkin, and R. Mumford. 2001. First report of Pepino mosaic virus in Canada and the United States. Plant Dis. 85:1121.

Goldbach, R. and D. Peters. 1994. Posible cause of tospovirus diseases. Semin. Virol. 5:113-120.

Jones, R.A.C., R. Koening, and D.E. Lesemann. 1980. Pepino mosaic virus, a new potexvirus from pepino (Solanum muricatum). Ann. Appl. Biol. 94:61-68.

Lacasa, A., M.M. Guerrero, I. Hita, M.A. Martínez, C. Jordá, P. Bielza, J. Contreras, A. Alacazar, and A. Cano. 2003. Implication of bumbles bees (Bombus spp.) on Pepino mosaic virus (PepMV) spread on tomato crops. Boletin Sanidad Vegetal 29:393-403.

Lankes, C. 2003. Response of selected Prunus rootstock clones to infection by Prune dwarf virus and Prunus necrotic ringspot virus. European J. Hort. Sci. 68:45-49.

Lisa, V., E. Ramazo, M. Ciuffo, and P. Roggero. 1998. Tomato apical necrosis caused by a strain of Parietaria mottle ilarvirus. Ninth Conference of the I.S.H.S.V.V.W.G., Recent Adv. Veg. Virus Res. Torino 1998. 3-5.

López, C., S. Soler, and F. Nuez. 2005. Comparison of the complete sequences of three different isolates of Pepino mosaic virus: Size variability of the TGBp3 protein between tomato and L. peruvianum isolates. Arch. Virol. 150:619627

Louro, D., G.P. Accotto, and A.M. Vaira. 2000 Occurrence and diagnosis of Tomato chlorosis virus in Portugal. Eur. J. Plant Pathol. 106: 589-592.

Marchoux, G., G. Parella, K. Gebre-Selassie, and P. Gagnalon. 1999. Identification de deux Ilarvirus sur tomate dans le Sud de la France. Phytoma 522:53-55.

Navas-Castillo, J., R. Camero, M. Bueno, and E. Moriones. 2000. Severe yellowing outbreaks in tomato in Spain associated with infections of Tomato chlorosis virus. Plant Dis. 84:835-837.

Pagán, I., M.C. Córdoba-Sellés, L. Martínez-Priego, A. Fraile, J.M. Malpica, C. Jordá, and F. García-Arenal. 2006. Genetic structure of the population of Pepino mosaic virus infecting tomato crops in Spain. Phytopathology 96 : 274-279.

Picó, B., M.J. Díez, and F. Nuez. 1996. Viral diseases causing the greatest economic losses to the tomato crop. I. The Tomato yellow leaf curl virus (TYLCV) - a review. Scientia Hort. 67:151-196.

Pospieszny, H. and N. Borodynko. 2002. Pepino mosaic virus. Prog. Plant Protection 42:83-87.

Roggero, P., M. Ciuffo, N. Katis, D. Alioto, A Crescenzi, G. Parrella, and D. Galliteli. 2000. Necrotic disease in tomatoes in Greece and southern Italy caused by the tomato strain od Parietaria mottle virus. J. Plant Pathol. 82:159.

Roggero, P., V. Masenga, R. Lenzi, F. Coghe, S. Ena, and S. Winter. 2001. First report of Pepino mosaic virus in tomato in Italy. Plant Pathol. 50:798.

Roselló, S., M.J. Díez, and F. Nuez. 1996. Viral disease causing the greatest economic losses to the tomato crop. I. The Tomato spotted wilt virus (TSWV) - a review. Scientia Hort. 67:117-121.

Salomone, A. and P. Roggero. 2002. Host range, seed transmission and detection by ELISA and lateral flow of an Italian isolate of Pepino mosaic virus. J. Plant Pathol. 84: 65-68.
Soler, S., J. Cebolla-Cornejo, J. Prohens, and F. Nuez. 2000. El Pepino Mosaic Virus (PepMV), una nueva amenaza para el cultivo del tomate II. Vida Rural 119:48-52.

Soler-Aleixandre, S., J. Cebolla-Cornejo, and F. Nuez. 2005a. Sources of resistance to Pepino mosaic virus (PepMV) in tomato. Tomato Genetics Cooperative Reports. 55:43-45.

Soler-Aleixandre, S., C. López, M.J. Díez, A Pérez-De Castro, and F. Nuez. 2005b. Association of Pepino mosaic virus with tomato collapse. J. Phytopathol. 153:1-6.

Stamova, B.S. and R.T. Chetelat. 2000. Inheritance and genetic mapping of Cucumber mosaic virus resistance introgressed from Lycopersicon chilense into tomato. Theor. Appl. Genet. 101:527-537.

Stamova, L. and M. Yordanov. 1987. Resistance to Leivellula taurica (Lev.). Tomato Genet. Coop. Rpt. 37:73.

Tomassoli, L. 2001. Pepino mosaic virus at the gates of Italy. Informatore Agrario 57:65-66.

Vaira, A.M., G.P. Accotto, M. Vecchiati, and M. Bragaloni. 2002. Tomato infectious chlorosis virus causes leaf yellowing and reddening of tomato in Italy. Phytoparasitica 30:290-294.

Wright, D. and R. Mumford. 1999. Pepino mosaic potexvirus (PepMV). First records in tomato in the United Kingdom. Plant Dis. Notice 89. Central Science Laboratory, York.

Zamir, D., I. Ekstein-Michelson, Y. Zakay, N. Navot, M. Zeidan, M. Sarfatti, Y. Eshed, E. Harel, T. Pleban, H. Oss, N. Kedar, H.D. Rabinowitch, H. Czosnek, and H. Van-Oss. 1994. Mapping and introgression of a tomato yellow leaf curl virus tolerance gene, TY-1. Theor. App. Genet. 88:141-146.

Zhang, Y., Z.J. Shen, J. Zhong, X.L. Lu, G. Cheng, and R.D. Li. 2003. Preliminary characterization of Pepino mosaic virus Shangai isolate (PepMV-Sh) and its detection with ELISA. Acta Agriculturae Shangai 19:90-92.

Zitikaite, I., J. Staniulis, R. Jomantiene, and P. Petniunas. 2004. Molecular and immunoelectron microscopic identification of Pepino mosaic potexvirus in tomato fruits imported from Spain. Botanica Lithuanica 10:89-98. 